\title{
Collectiondevelopment.com
}

\section{Using Amazon.com and other online bookstores for collection development}

\author{
by Monica Fusich
}

$I^{n}$ n 1995, Amazon.com began a service that became one of the first virtual bookstores not allied to an existing bookselling business. It billed itself as "Earth's bookstore." Many other bookstores, both independents and national chains alike, have also established a presence on the Internet. Currently, Yahoo's Business and Economy: Companies: Books page links to over 230 online stores, highlighting the popularity of this format. Virtual bookstores are popular with customers because they provide many services, such as notification, subject searching, and reviews, all from the comfort of one's home or office.

In addition to being popular with consumers, librarians can use many of the services offered by

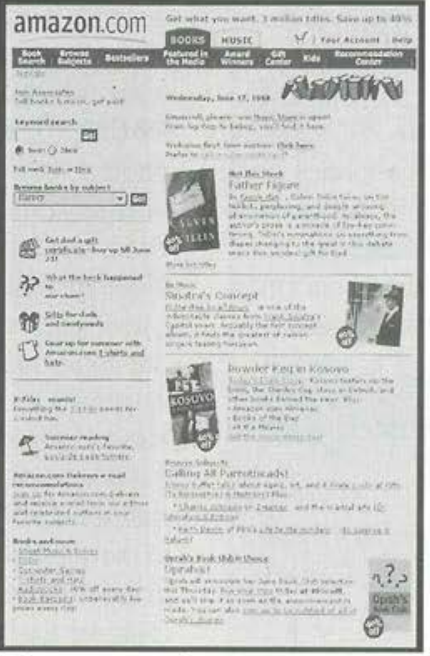

Photo courtesy of Amazon.com library uses traditional vendors and approval plans for book ordering, Amazon.com has several helpful services, such as the cumulated book reviews, search and browse features, and notification services, which are of great assistance when carrying out my collection-development duties. Though I use Amazon.com principally, other Internet booksellers, such as Waterstone's, Barnes and Noble, and Borders offer similar options.

\section{An extensive database}

One of the strengths of Amazon.com is the size of its database, which includes 3 million in-print and outof-print book and recorded music titles. Though there are 3 million titles in the database, Amazon.com keeps only the top 400 book titles Amazon.com and other Internet bookstores when developing a library's collection. Although not a substitute for a well-developed collection development strategy, Internet bookstores have features that librarians can use to enhance traditional collection development processes and programs. I have been using Amazon.com mainly when doing collection development in the areas of art, art history, design, and fashion. Although our in stock. The rest are ordered from the Ingram Book Group, which is a wholesale provider to many Internet booksellers.Amazon. com's extensive database is one of the main reasons to first search here to determine the availability of a title.

Amazon.com has a well-developed search engine that allows quick and easy access to the database. There are three search options: quick, author-title-subject, or power search.

\section{About the author}


Quick Search is a basic keyword search. The author-title-subject search engine is the one I find the most helpful and use most frequently. It allows searching by exact start of title, author, or subject; title, author, or subject keywords; or start of title, author, or subject words. This last feature is especially helpful when only part of a title or author's name is remembered. Other search options include searching by ISBN, publisher, or date.

Be warned that although the search engines are easy to use and excellent documentation is provided, there are quirks. For example, when I searched "Guerrilla Girls" (a group of anonymous female artists who use this name to challenge the male-dominated art world) as an author, I got the title I was looking for as well to links to any titles that had "girl" in the title. Another search I tried was for Witbout My Cloak by the Irish author Kate O'Brien. Amazon.com stated this title was out of print. However, this book is in print and available from Waterstone's.

\section{No sweat browsing}

In addition to specific searching, Amazon.com offers browsing in 28 subject categories, each subdivided into subcategories. Art, for example, is divided into 14 subcategories. Each subcategory links to 50 of Amazon.com's most popular titles. This feature is a quick and con-

\section{Virtual bookstores}

\section{Amazon.com}

www.amazon.com

\section{Barnes and Noble}

www.barnesandnoble.com

\section{Book Stacks}

http://www.books.com/scripts/default.exe

\section{Internet Bookshop}

http://www.bookshop.co.uk/HME/ HMEPGE.ASP

\section{Waterstone's}

http://www.waterstones.com/index.htm

Yahoo: Business and Economy: Companies: Books: Booksellers

http://www.yahoo.com/Business and_Economy/Companies/Books/ Booksellers/Sidebar venient way to see and order what is popular and currently available in a field.

Once a book has been located either by searching or browsing, Amazon.com offers a variety of information about the title. In addition to the bibliographic information, records can include an excerpt of the first chapter or an interview with the author. Amazon.com has an interview form available at the site that authors can use and that is then uploaded as an interview. In addition, a reproduction of the book jacket is included.

Book reviews by Amazon.com staff; media such as Publisher's Weekly, Kirkus Reviews, or the New York Times Book Review; and reviews by customers are attached. I find the reviews by the general public to be extremely helpful. The subject headings used to index the book are listed at the end of the record and can be checked to locate similar books. In one place, one can read both professional and reader opinions, see an image of the book, and locate related titles.

\section{Notification and review services}

Another option that Amazon.com and other Internet booksellers offer is notification services. Amazon.com Delivers allows the user to set up a subject profile and be notified by e-mail when specific titles are published. The categories are broad, but one can also set up a word search through Amazon.com Eyes. Though not all categories are activated at this time, this can be used as a current awareness service. When the e-mail message is sent to the subscriber, it includes hypertext links to the titles in Amazon.com so one need only click on the link to locate information on the title.

In addition, Amazon.com offers a "Reviewed in the Media" section. Eight TV and radio programs, eight newspapers, and twelve magazines are listed on this page. It is easy to assume that the reviews came from the source named. However, the reviews attached to the titles listed are not necessarily from that particular source. For example, when I chose book reviews in Vanity Fair, I pulled up a list of titles reviewed in the June issue. The reviews, however, were from other sources, such as Kirkus Reviews, the New York Times Book Review, or the Wall Street Journal. 


\section{An important point about}

\section{Internet bookstores is that there}

is no cost to use them.

\section{More features}

Other Internet bookstores offer additional features. Barnes and Noble offers a magazine category. It lists magazines by subject such as arts and entertainment, bridal, education, and fashion and style. Within the subject area are links to specific magazine titles. Each entry for a magazine includes a description of the content and purpose of the magazine, a reproduction of a current cover, and subscription information. Another service offered by Book Stacks is book forums.

A variety of chat rooms are available for users to post and read messages. Some of the forums currently offered are lateral thinking, fiction, and computer books. The book forums, like chat rooms on other topics, are an additional way to gather information. Internet Book Shop has a helpful refinement to its search engine. It gives the option of sorting search results five different ways. Titles can be sorted either alphabetically within category, alphabetically by title, by publication date, by price, or alphabetically by author.

\section{Benefits}

An important point about Internet bookstores is that there is no cost to use them. Choice now has an online beta test site for its reviews, but libraries will have to subscribe to this service. By contrast, librarians can freely and effectively use virtual bookstores.

In addition to the lack of cost, Internet bookstores provide information much more quickly than reviews in print media or collection development sources. This information is enhanced by notification features, which send information to an individual in contrast to the traditional way librarians use print book review resources.

Amazon.com and other virtual bookstores are not a substitute for traditional collection development practices. However, they are convenient and expedient and offer many services that can be used creatively by librarians to supplement current collection development methods.

\section{Sociological Abstracts now has a new address:}

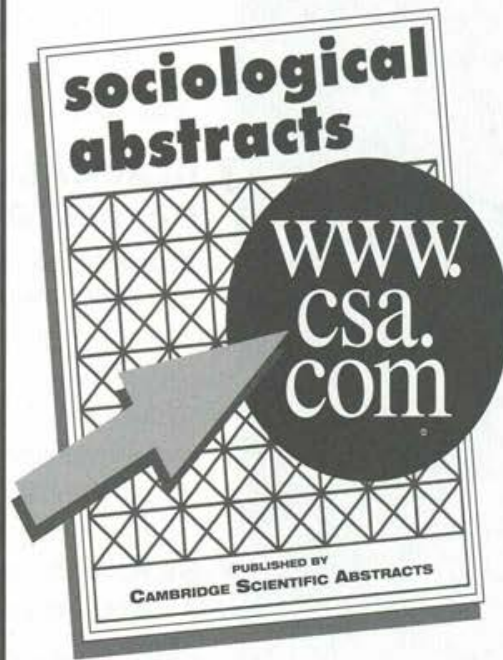

Now Available on the Internet Datahase Service From Gambridge Scientific Abstracts - Site-wide, Unlimited Use Subscriptions

\begin{tabular}{|c|}
\hline Special Introductory Offer \\
\hline Sociological Abstracts (1963 - present) \& \\
ERIC (1966 - present) via the Intemet Database Service \\
$\mathbf{\$ 3 , 0 0 0 / y e a r ~}$ \\
Site-Wide Access, Unlimited Use \\
\hline
\end{tabular}

Over 40 databases in diverse scientific and technical disciplines are available on the Internet Database Service.

Contact Gambridge Scientific
Abstracts for complimentary
30-day access!




\section{State of the Art Technology for Information Management}

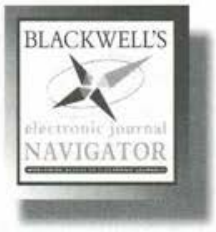

BLACKWELL'S ELECTRINIC JUURNAL NAVIGATIR

ACCESS TO ELECTRONIC JOURNALS THROUGH A SINGLE WEB-BASED USER INTERFACE.

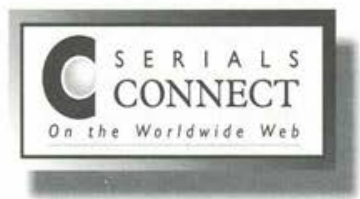

SERIALS CINNECT IN THE WORLDWIDE WEB

EASY-TO-USE WORLDWIDE LINK TO QUR UNIQUE DATABASE OF SERIALS AND SERIES INFORMATION.

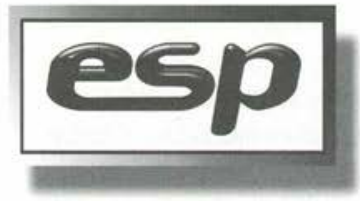

\section{ELECTRINIC SUBSCRIPTION PRDVIDER}

ACCESS TO A RANGE OF CD-ROM DATABASES FROM A VARIETY OF PUBLISHERS OVER THE INTERNET.

QUR ELECTRONIC SERVICES ARE SPECIALLY DESIGNED TO PROVIDE A SINGLE SOURCE OF ELECTRONIC SUBSCRIPTION INFORMATION TO ACADEMIC AND RESEARCH LIBRARIES. WE WORK IN CLOSE PARTNERSHIP WITH CUSTOMERS AND PUBLISHERS TO PROVIDE PRODUCTS AND SERVICES DESIGNED FOR INDIVIDUAL CUSTOMER NEEDS.

\section{BLACKWELL'S}

INFORMATION SERVICES

New Jersey Sales Office

PO Box 1257, Blackwood, NJ 08012 • Phone: 800-458-3706 • Fax: 609-232-5397

http://www.blackwell.co.uk 